\title{
Multi-Scalar Localization and Capability Transference: Exploring Embeddedness in the Asian Retail Expansion of Tesco
}

Steve Wood ${ }^{1}$, Neil M Coe ${ }^{\circ}$, Neil Wrigleyx

${ }^{1}$ The Surrey Business School, University of Surrey, Guildford, Surrey GU2 7XH, UK. Email: sm.wood@surrey.ac.uk

${ }^{\circ}$ Department of Geography, National University of Singapore, AS2, \#03-01, 1 Arts Link, Kent Ridge, Singapore 117570

Email: geonmc@nus.edu.sg

$\times$ Geography \& Environment, University of Southampton, Southampton, SO17 1BJ, UK.

Email: $\underline{\text { n.wrigley@soton.ac.uk }}$

Accepted draft manuscript for Regional Studies, May 2014.

If citing please refer to the final version in the journal

\section{ACKNOWLEDGEMENTS}

We would like to thank Matthew Truman and Paul Diamond at JP Morgan; James Anstead at Barclays Capital; Clive Black at Shore Capital and Dave McCarthy at Evolution Securities for estimates and information concerning Tesco performance. Finally, we appreciate the helpful and constructive comments of anonymous referees in helping to improve this paper. All errors and omissions are the responsibilities of the authors. 


\title{
Multi-Scalar Localization and Capability Transference: Exploring Embeddedness in the Asian Retail Expansion of Tesco
}

\begin{abstract}
This paper revisits the "firm in the region" and the "region in the firm" dichotomy through the case of Tesco's retail expansion in Asia. It focuses on the tension between the transference of proven key capabilities to the host economies Tesco has entered, and strategic localization, primarily for customer-facing, corporate culture, regulatory and institutional reasons. We demonstrate how the retailer has pursued a multi-scalar adaptive approach that goes beyond any standardized/localized dichotomy to respond to differences between and within national markets. In the process, we provide evidence of genuine two-way knowledge flow between the home market and subsidiaries, between subsidiaries themselves, and of subsidiaries granted autonomy and the ability to flex their strategies.
\end{abstract}

Keywords: retail TNC, global retail, embeddedness, localization, scale

JEL classifications: $\quad$ L2 (Firm Objectives, Organization, and Behaviour)

L81 (Retail and Wholesale Trade/Warehousing)

F23 (Multinational Firms/International Business) 


\section{INTRODUCTION}

How are subsidiary businesses regarded and treated by a seemingly all-powerful parent? To what degree are they granted autonomy and the ability to flex their strategies in order to gain relevance and traction given the particularities of the markets which they enter and expand within? Here we argue that some indication of the nature of those relationships between core and periphery can sometimes be seen within small details. For example, at multinational food retailer, Tesco plc, the format of the email addresses of its retail subsidiaries offers, perhaps inadvertently, insight into the firm's approach to international expansion. Instead of the priority being assigned to the firm (@ tesco.china.com), the host market is given prominence (@ china.tesco.com). In a small and subtle way then, this shows that the retailer places emphasis on the subsidiary's operating space, forgoing a homogenous approach - something that feeds throughout the business and represents a considered mediation between the realization of central efficiency and "best practice" on the one hand, and adaptation and local embeddedness on the other. As Tesco Chief Executive, Philip Clarke, has argued:

We will win locally by applying our skills globally. The key word here is 'locally'. Seven years of running our business in Asia and Europe has taught me that all retailing is local (TESCO PLC, 2011, p 4)

Such concerns have strong roots within economic geography, regional studies, international marketing and business studies. The international expansion of firms is well-known to exhibit a tension between control and strategic planning from the centre and the local demands of the subsidiary operation. Traditionally, views concerning the nature of this relationship were unidirectional - the head office was seen as dictating and retaining close control, with the knowledge generated by the subsidiary being of little relevance for the home market or other subsidiaries. As SCHOENBERGER (1999) recalled, the prevailing view was one of the firm being in the region but of the region failing to influence the firm, its knowledge bases or its practices.

Over the past decade, of course, this view has fundamentally changed. Indeed, in his conceptualization of the geography of expanding TNCs, DICKEN $(2000 ; 2003)$ drew on the distinction between what he termed 'placing firms' on the one hand - that is to say understanding where firms come from, the DNA which they derive from their home market and the effects that this has for their approach to realising expansion and subsequent operations - and on the other hand, 'firming places' - understanding the development of the 
organizational space of the business through intra-, inter- and extra-firm organizational relationships. Likewise, AMIN and COHENDET (2004) demonstrated that the flow of knowledge within internationalizing firms must reflect these distinctions drawn by Schoenberger and Dicken. That is to say, the two-way nature of knowledge flow - or as CURRAH and WRIGLEY (2004) put it, simultaneously "top-down" and "bottom-up" - is critical to understanding the nature and performance of TNCs.

Specifically in the study of transnational retail operations, which WRIGLEY (2000) noted had previously lagged the general trends within economic geography, the dimension of the 'region in the firm' is of particular significance. As has subsequently become recognized, placing the region in the firm and encouraging localization to achieve 'organizational legitimacy' of the business in the host economy is almost always critical to the performance of those firms (BIANCHI and ARNOLD, 2004). Such concerns have been framed within economic geography in terms of ensuring the retailer is 'territorially embedded' within its host environment (HESS, 2004; WRIGLEY et al., 2005) or 'strategically localized' (COE and LEE, 2006; 2013).

In this paper we examine the approaches that Tesco has employed to achieving embedded expansion across its rapidly growing Asian operations. More specifically, the research contributes to wider debates within regional studies and economic geography in assessing how pressures for standardization versus localization play out unevenly by geography and by area of activity. For the transnational retailer, this strategic challenge demands continual (re)assessment of the interplay between centralization and decentralization. In doing so, our analysis explores the need for a multi-scalar approach that looks at regional dynamics (here used to refer to the 'Asian' level); at the scale of the national market; and at sub-national dynamics (i.e. intra-country variations) rather than simply the global versus national market dichotomy usually found in literature. In the process, we start to uncover the manner in which the retailer effectively responds to SCHOENBERGER'S plea for 'the region to enter the life of the firm to a much greater degree' (1999, p 222).

Our focus on Asia is especially important given Tesco's strong store, sourcing and supply chain presence and its performance across the continent, but also the wider region's 'leading edge' status in terms of digital connectivity and commerce. As Tesco Chief Executive, Philip Clarke put it recently, 'our digital innovation is being driven and refined by the demands of our 
Asian markets', which itself demands 'tailoring that presence to what our customers need...[a] powerful blend of global strength and local understanding' (TESCO PLC, 2013).

We achieve our objectives through the interrogation of an array of secondary industry data but also vitally through 'close dialogue' (CLARK, 1998) with leading UK based food retail equity analysts who provide detailed analysis of the company and wider market, primarily for institutional clients. These insights are important for our purposes as they are informed by privileged access to the company above and beyond that likely to be available to any independent academic researcher. Equity analyst networks are notoriously difficult to access (WRIGLEY et al., 2003) but have been employed with success in economic geography and management studies to explore global retailing (e.g. WRIGLEY and CURRAH, 2003; CURRAH and WRIGLEY, 2004; PALMER and QUINN, 2007). We have built ongoing relationships with a number of leading analysts over a number of years and used this knowledge to inform our study. Particular analysts were selected for inclusion in the research based on their consistent coverage of the firm over a lengthy period and their profile within the financial market. We are conscious of concerns regarding the accuracy of analyst accounts and their closeness to management which is a benefit as well as a potential limitation (WESTPHAL and CLEMENT, 2008). In addition, of course, 'close dialogue' such as this raises concerns over possible 'seduction' and 'cooption' (CLARK, 1998, p 80) - that is to say, becoming duped by 'stories in the process of formation and competition for dominance', and constructed to 'deliver a particular set of accumulation outcomes' (O'NEILL, 2001, p 194). However, we have considerable experience in employing this method and use extensive triangulation to mitigate these potential problems. We have used 'within-method' triangulation to mitigate these potential problems in terms of contrasting different equity analyst viewpoints over time, but also 'between-method' triangulation in accessing and analysing recordings of management results presentations and associated investor Q\&As, reviewing the insights from national and local media sources, and through discussions with retail industry consultants who have firsthand knowledge of Tesco's expansion. Therefore, our insights are both empirical and conceptual and derive from working 'backwards and forwards between theory and the empirical world in a reflexive manner' (CLARK, 2007, p 191).

Our paper is structured as follows: first, we briefly reflect on the multi-disciplinary research within the social sciences concerning the challenges of international retail expansion. Second, we introduce the economic geography of Tesco and its Asian operations. Third, we analyse 
how the retailer mediates between the "the firm in the region" and "the region in the firm" in its Asian operations across a variety of spatial scales. We conclude with a discussion of the relevance of these findings for research into international business expansion within the social science literature more widely.

\section{THE CHALLENGE OF INTERNATIONAL RETAIL EXPANSION - ECONOMIC GEOGRAPHY AND BUSINESS MANAGEMENT PERSPECTIVES}

The international business and marketing literature explores the need for transnational businesses to 'balance local responsiveness and central coordination' (CHINI, 2004, p 37). While many theoretical frameworks from international business studies are inappropriately applied to studies of international retailing (DAWSON, 2007), the retail expansion challenge can be usefully expressed through the Integration-Responsiveness (IR) framework that details four broadly defined strategies that are related to the pressure for global integration and efficiency versus pressure for local responsiveness within host markets (see Figure 1). Such a perspective, recently imported into retail studies (e.g. SWOBODA et al., 2012), provides greater nuance to the dichotomy between a highly responsive "multinational" approach and a replication "global" retailer strategy outlined by SALMON and TORDJMAN (1989). Indeed, the mediation between the centre and the periphery is defined partly by the internal resources that the firm commands, but is also affected by the external resources it can access in specific host markets - a view that is consistent with the 'resource bundling' theory of transnational enterprise more generally (RUGMAN et al., 2011; HENNART, 2009). Consequently, retail TNCs are likely to operate a portfolio of differentiated but inter-dependent subsidiaries.

Figure 1 about here

SWOBODA et al. (2012) find that food retailers have to generate a higher degree of local advantages and responsiveness because they experience greater pressures to adapt assortments to local tastes and to construct supply chains within each host country. In contrast, they suggest that non-food retailers face a higher degree of global competition and lower local advantage as they tend to develop more standardized assortments across countries and integrate supply chain processes more easily. In relating empirical survey results to the I-R framework, SWOBODA et al. find that the 'International' strategy was least successful, whereas the 'Transnational' strategy proved most effective. The model provides important insights for our conceptualization of managing retail expansion in its demonstration of differing degrees of 
knowledge/capability transference and adaptation in international retail expansion. However, the conceptualization has been criticized for underplaying the complexity of different aspects of the value chain that may exhibit different degrees of integration and responsiveness within individual subsidiaries (RUGMAN et al., 2011). In addition, the framework is typically conceptualized in terms of home country to subsidiary country adaptation and tells us less about intra-country regional variation and localization - an aspect where this paper particularly contributes to the body of knowledge.

Economic geographers have framed the challenge of international retail expansion in terms of attaining three related forms of embeddedness within a host market ${ }^{1}$. This is extensively discussed elsewhere (e.g. WRIGLEY et al., 2005) and summarized in Table 1.

Table 1 about here

Processes of adapting the retail firm to the region involve reflection on the appropriateness of the operator's 'format and formula' for the host market (DAWSON and MUKOYAMA, 2014). This particularly requires close consideration of the suitability of a particular store format, marketing proposition, product offering, store and supply chain operations, and HR management, for example. Adaptation at multiple scales can unsurprisingly take considerable time, and is unlikely to be complete at the point of market entry, despite many retailers undertaking thorough pre-entry research ( $c f$. LOWE and WRIGLEY, 2010; WOOD and REYNOLDS, 2012b). Territorially embedding the business is something that involves acclimatisation to (and establishment within) real-estate and land-use planning, knowledge networks, supply networks, and cultures of consumption (WRIGLEY et al., 2005). Indeed, COE and LEE (2006; 2013) highlight the need for the continued evolution of territorial embeddedness encompassing format innovation, the deepening and reshaping of supply networks, and the expansion of the product range offered. Similarly, JONSSON and FOSS' (2011) analysis of IKEA's reveals substantial intra-market refinement of the retail proposition both pre- and post- market entry. Such longitudinal adaptive processes contrast with a view from international business that advocates more of a mechanical replication of a proven formula following a period of experimentation (WINTER and SZULANSKI, 2001).

The processes of localization - and the extent to which local tailoring is necessary at all - is complicated depending on how unique an array of factors are to the retailer including the 
institutional context, business customs, supplier and customer base and competition within the region. Influential work conceptualizing the challenges presented by 'particularistic', 'collaborative' and 'arm's length' business environments have partly explained differing modes of international retail expansion (WRIGLEY and CURRAH, 2003; WRIGLEY et al., 2005; OKEAHALAM and WOOD, 2009; WOOD and REYNOLDS, 2012b; $c f$. WHITLEY, 2001).

International retail expansion is a situationally dependent process that represents a complex interplay between importing efficient operational best practice from elsewhere in the retail business and adaptability for continental, national and sub-national regions - what JONSSON and FOSS (2011) refer to as 'flexible replication'. An uncritical direct transfer of managerial practices and competencies is often directly resisted (HURT and HURT, 2005) meaning that any binary conceptualization of the 'firm in the region' or the 'region in the firm' is simplistic and a more nuanced picture of international food retail expansion becomes evident. What emerges - as the business and management literature refers to them - are practices of 'hybridization' ( $c f$. GAMBLE, 2010; LOWE and WRIGLEY, 2010) - something recognized as 'the creation of new management practices out of selective adaptation, innovation and change' (MORGAN, 2001, p 114). Some operational capabilities or practices may be successfully directly transferred, but it is more likely such replication will be partial and significantly amended for national or sub-national regional cultures, institutional business contexts and the nature of specific industry sectors (DURAND and WRIGLEY, 2009; GAMBLE, 2010).

Organizationally and operationally this is challenging. As part of expansion and adaptation processes, MEYER et al. (2011) identify the need for embeddedness at two levels. On the one hand, there is the need to embed a portfolio of subsidiary firms in numerous heterogeneous contexts which requires the firm to interact with a range of actors who operate in quite different local contexts, and then to formulate appropriate strategies without becoming overwhelmed. On the other hand, the retail subsidiary must interface and balance its local responses with the global integration and efficiencies of the wider retail parent company and its operating procedures (ALMEIDA and PHENE, 2004). Or, as MEYER et al. (2011, p 236) put it, be “"externally embedded' within each local context while also being sufficiently 'internally embedded' within the MNE network for the benefits of external embeddedness to be potentially available to the rest of the MNE'. Of course this necessitates a certain degree of devolved decision-making at the level of the subsidiary retail operation, while also maintaining 
an open dialogue and information flow with its parent (MUDAMBI and NAVARRA, 2004). Consequently, the retail TNC is widely regarded to function as a set of differentiated networks, rather than as a hierarchically run organization with national subsidiaries playing homogenous roles ( $c f$. RUGMAN and VERBEKE, 2003).

Characterizing the interface between the retail TNC headquarters and its subsidiaries as twoway emphasizes the ability for knowledge to flow from the region, back to the core of the retail business to allow it to inform strategies and approaches elsewhere. This also provides the opportunity for knowledge to flow between subsidiary operations (WANG, 2009) and demands a high degree of 'absorptive capacity' within the retail organization (COHEN and LEVINTHAL, 1990). For truly "transnational" retailers, knowledge is likely to flow both ways - both from "top-down" and "bottom-up". Hence there is scope for learning and knowledge to flow back from the overseas subsidiary to other international operations and possibly the home market itself, albeit in a slightly amended form - in the phraseology of LOWE et al. (2012), a demonstration of splicing (the creation of new capabilities through recombination of elements of extant capabilities from multiple locations). Such subsidiary influence on the transnational firm is increasingly recognized within the management literature (ANDERSSON and PAHLBERG, 1997; ANDERSSON et al., 2007). These experiences see the retailer's stock of knowledge increase with 'large-scale grafting of new capabilities' between locations (BIRKINSHAW and HOOD, 1998, p 781).

Our analysis of Tesco's Asian operations provides an interesting and informative case upon which to explore these processes that has significant relevance for economic geography and international business studies more widely. While arguably an 'extreme case' given the retailer's extensive international experience and proven expertise, its selection serves to elucidate the embeddedness challenges characteristic of international retail expansion. While the reviewed research recognizes the tension between any global replication and localization, this is commonly framed in terms of retailer adaptation to variegated national institutional, societal and regulatory environments - our focus seeks to further develop the understanding of this phenomena, but also explore retailer localization within sub-national regions of subsidiary businesses. Our analysis therefore aims to expose more explicitly the extent of these multiscalar aspects of localization and capability transference in transnational retail expansion. 


\section{THE EMERGENCE OF TESCO AS A TRANSNATIONAL RETAILER}

Tesco has emerged as a major international retailer in a relatively short period of time, growing rapidly from a domestic UK base since the early 1990s to operate a store portfolio with coverage across Central and Eastern Europe and Asia, in the process becoming the $7^{\text {th }}$ largest retailer rated by international sales (Table 2). It is now participating in markets that represent over half of global GDP versus only $8 \%$ in 2000 and holds the No. 1 or No. 2 market position in nine of its trading markets (SHORE CAPITAL, 2010a).

Table 2 about here

The international phase of development effectively commenced with the acquisition of French supermarket chain, Catteau in December $1992^{2}$. While this particular market entry stalled and ultimately led to market exit four years later due to Tesco's apparent inability to compete in a market replete with large stores and a recently tightened land-use planning regime, the retailer learned a considerable amount from the venture - especially the need for a thorough appraisal of new regions and an understanding of the risks associated with entry into already developed retail markets (PALMER, 2004; 2005). The retailer subsequently made a number of acquisitions of (or joint ventures with) food retailers across underdeveloped European retail markets: notably Hungary (1994), the Czech Republic and Slovakia (1996), Ireland (1997) and Poland (2002).

Crucially these small acquisitions committed minimal sunk costs yet offered Tesco footholds within national markets from which it could learn from a successfully embedded (and often domestic) retailer. These markets (with the exception of Ireland) also offered the potential to roll out a hypermarket format (DAWSON et al., 2006). As the European business was being developed, a similar strategic approach was adopted in Asia with market entry - commonly through a joint venture or modestly-sized acquisition partner - pursued across an array of locations including South Korea, Thailand, Japan, Malaysia, China and Taiwan (see Table 3).

International expansion was framed partly as a transfer of knowledge from the home to the local market but with some tailoring for local preferences:

Our formula is to develop a world-class hypermarket format with a common layout, common operations and common systems, overlaid with local marketing, local services, local staff and local management (Tesco PLC, 2000, p 3). 
But also, there was awareness that expansion would involve learning and that such knowledge would flow back from the international subsidiaries: 'we are developing new skills and experience from these businesses which we can put into practice in the UK and around the world' (TESCO PLC, 1999, p 14). These multi-directional knowledge flows occur before, during, and after the point of market entry - something we investigate in greater depth in terms of the Asian operations later in the paper.

The focus of this paper is explicitly on exploring strategic growth within the Asian business of Tesco. By the 2011 year-end, it was estimated that Tesco had invested a total of $£ 6.9 \mathrm{bn}$ of capital in the continent. During 2011/12, Tesco Asian retail sales equated to $£ 11.2 \mathrm{bn}$ (see Table 4 for splits between Asian countries). It is particularly notable that there remained substantial potential for market share growth within each of these Asian markets ( $c f$. in the UK, Tesco has a circa. $30 \%$ market share).

Tables $3 \& 4$ about here

Given the challenging nature of international food retail expansion, it is unsurprising that there have been failures by Tesco within Asia. Entry into Taiwan never proceeded beyond 5 hypermarkets, having entered the country in 2000 somewhat late as the market was no longer underdeveloped, but instead offered considerable western competition given the presence of several strong retail TNCs including Carrefour, Casino (Geant) and Auchan (RT Mart). The retailer eventually divested its stores through an agreement with Carrefour in 2005. Tesco has also recently acknowledged defeat in Japan - a fragmented grocery market. The retailer departed from its 'hypermarket-first' approach to market entry and failed to achieve market scale - a problem exacerbated with its failure to subsequently make any significantly sized acquisitions. In August 2011, the retailer announced the decision to divest, and in June 2012 confirmed an agreement with Aeon, Japan's largest retail group, to exit the market in two stages.

Critically, both of these failed business ventures departed from the expansion mode that had typified successful growth elsewhere in Tesco's international business. In both instances Tesco failed to work with a sizeable partner to provide initial critical mass, meaning that the retailer was unlikely to ever achieve a leading position in the market. In addition, Japan 
particularly was already a developed retail market - something that the Tesco had generally avoided between the disastrous expansion into France in 1992 and the recently acknowledged failed entry into the USA in 2007. These two Asian divestments contrast with the performance and growth in Thailand, South Korea and, to a lesser extent, Malaysia.

Tesco has approached international expansion through a staged strategy of constructing a store network and developing the associated support functions; building the brand by importing private label ranges and relationship marketing tools; and then extending that brand through aligned services such as mobile telephony and financial services (see Table 5).

Table 5 about here

Over the remainder of the paper, we explore how Tesco has addressed the multi-scalar aspects of localization and capability transference across its Asian operations. We present this analysis through the following thematic structure for illustrative purposes - in reality, of course, most activities are to some degree combinations of global and more localized practices:

(1) The firm in the region - establishing elements of transferable best practice in international retail operations, formats and principles of operation, and then:

(2) The region in the firm - via (a) Strategic localization - essentially placing the region within the firm and overseeing considerable adaptation to realise territorial embeddedness within the region; (b) Intelligently transferring these practices and knowledge from regional operations (where appropriate) to the wider firm and its other international operations.

\section{THE FIRM IN THE REGION (TRANSFERING CAPABILITIES TO ASIA)}

Given the desire for economies of scale and scope, standardization is attractive as it realises the benefits of the wider Tesco business. Referred to by LOWE et al. (2012, p 14) as 'transference', this represents 'the deployment of inter-dependent tasks and capabilities in multiple environments without local modification'. Such capabilities particularly attuned to transference are often back-office rather than customer-facing aspects of retail development and therefore less important to localize for local, national or regional cultures of consumption. 


\section{Store construction, design and merchandising}

Given that the Asian market has been more receptive to the classic "big box" hypermarket format than some parts of Central Europe, where the Germanic discounter approach has often flourished, Tesco initially developed the hypermarket format across many of its Asian businesses. The transference from the home market is considerable with significant leveraging of Tesco's competencies in store design between countries. These "blueprints" represent a systematization of both store and distribution centre design that economises on the sourcing of materials and in construction but also leads to subsequent operational efficiency given standardized space and merchandising capacities:

The blueprints codify guidelines for the sales area, design standards, operating procedures, people plans and financial insight. They also allow us to build for less as we standardise building specifications and fixtures and fittings for Group scale buying (TESCO PLC, 2011, p 47)

However, transference extends beyond the blueprint for a store or distribution centre to encompass the operating model of the retailer. This entails exporting a range of capabilities across the international business, such as labour scheduling, order and supply chain processes, and transport and planning systems. The Tesco Operating Model evolved from the so-called "Tesco-in-a-Box" initiative that is a well-defined process from planning and building a store, to the processes underpinning its operation (ZAINO, 2009). Its standardized applications and systems include the technologies that support the stores, such as the highly responsive demandpull lean supply chain that allows the tracking of quantities of products sold in each store and communicates accurate reorder estimates with partners. As such, merchandise planning has seen substantial investment within Tesco's Asian markets - for example, planograms have been fully implemented in the Korean business ${ }^{3}$. This allows the retailer to be far more discriminating about the returns it receives in relation to the spatial allocation of product lines, allowing profitable timely amendments to merchandising across its store portfolio - a characteristic uncommon at many other international retailers. The transferable Tesco operating model has understandably been described as "the mortar or glue that both holds the bricks of the business together and the oil that keeps the engine running' (SHORE CAPITAL, 2011, p 21).

\section{Sourcing and distribution networks}


The transference of efficiencies are deepened through the use of global sourcing networks something that is often discussed in economic geography research in relation to clothing (ABERNATHY et al., 2006; TOKATLI, 2008) - but is also critical in wider general merchandise. Indeed, much non-food (both clothing and hard lines, such as electricals, homewares, toys) that is centrally sourced flows through the Tesco international sourcing office based in Hong Kong which was responsible, in 2009, for buying 100,000 non-food products for the group. 2009 also saw the start of this sourcing hub being used to support the Asian operations, alongside additional sourcing hubs in China, India, Sri Lanka, Bangladesh and Turkey, with smaller offices in Thailand, Czech Republic and Italy (TESCO PLC, 2009). In addition, Tesco's South Korean food sourcing benefits from the Shanghai Asia Commercial Team that was established in the Spring of 2007 (MURPHY, 2008) and in its first year of operation shipped 1,231 non-food and four fruit lines to Samsung-Tesco (COE and LEE, 2013). By benefitting from agglomeration economies with numerous suppliers situated in strategic sourcing locations and exploiting the efficiencies of associated shipping volumes, cost prices are substantially reduced.

The centralization of sourcing carries with it a risk of losing sensitivity to local consumer demands, though these dangers can be reduced by local retail teams involved in the process. Importantly, when such efficient sourcing networks are established and unlocked, they potentially provide a sustainable source of competitive advantage given that they 'cannot readily be copied by other operators' (BOAML, 2011, p 7). Of course, a related threat that is readily discussed within the research literature is the manner in which retail TNCs can be regarded as a highly efficient 'trojan horse' for imported goods that become understandably feared by host governments (REARDON et al., 2007) - something notably evident in Walmart's entry into Mexico (DURAND, 2007). In contrast, COE and HESS (2005) examine Tesco's operations in Central/Eastern Europe and identify a declining share of imports by retail TNCs over time as local supply capacity increases due to the upgrading of supply networks within the host region. Given both the perishability and culturally sensitive characteristics of food, global sourcing is less viable, especially for fresh food. This means that regional sourcing networks have to be established within Tesco's international operations - an aspect where the retailer's European operations were initially quicker to develop than in Asia (DAWSON et al., 2006). 
Such pressures have led Tesco's Asian operations to partially replicate the UK model of local suppliers delivering directly to retailer-owned regional distribution centres - a process that underpins highly efficient food retail logistics (GUSTAFSSON et al., 2009) - but which also provides a platform for further format diversification, innovation and experimentation:

Once the distribution network is in place there is a kick up in cash returns through more effective buying, lower store operating and distribution costs (with fewer direct deliveries), and working capital progress - central distribution also allows for format diversity (SHORE CAPITAL, 2010b, p 45).

As DAWSON et al. (2006, p 194) suggest, with a relatively limited store base of 20-25 hypermarkets, 'centralized logistics becomes economical'. For example, in South Korea, Tesco opened a start-of-the-art fresh goods distribution centre in 2005 to accompany the dry goods distribution centre which had opened previously in 2002, while in 2008 the company announced a US $\$ 100$ million investment in a 120,000 square metre logistics service centre in Ansung, Gyeonggi Province, later completed in 2010 (COE and LEE, 2013). The centrally held knowledge and expertise in sourcing, logistics and supply chain allows Tesco to construct regional sourcing networks with established standards of food safety and ethics. For example, in South Korea only $10 \%$ of products are sourced from abroad, as many of the large fastmoving consumer good (FMCG) firms themselves have operations within the country itself. Over the period 1999 to 2008 , the company increased its number of suppliers from 1,023 to 3,718 with the majority of vendors among the top 20 being local companies (COE and LEE, 2013).

A similar approach to developing local in-country sourcing is evident in Tesco's Malaysian operations. NOMURA CAPITAL (2009) report some 95\% of its overall product lines are sourced in-country with some moves to make the country an 'export gateway' to Tesco stores in the British market. Localized sourcing makes business sense but is also astute given the case studies of resistance against retail TNCs that have not been so sensitive in their realisation of territorial and network embeddedness ( $c f$. FRANZ, 2010; 2012).

\section{The retail brand, loyalty and culture}

Tesco's global sourcing competencies and the scale of a growing international footprint permit sub-brand or private label development in non-food which can be leveraged across the Asian businesses. Private label apparel, "F\&F" branded ranges are increasing their penetration in the 
sales mix, as is the tiered range architecture of "good, better, best" that has been a feature of the UK operation for nearly twenty years. However, there remains substantial opportunity to further develop these ranges given that own-label penetration stands at 8-10\% for food and a lot lower in non-food across many of the international operations (NOMURA CAPITAL, 2009). Unsurprisingly, there have been recent moves to significantly increase the prominence of own label ranges in the sales mix. In the Korean Samsung-Tesco business, for example, own brand participation has increased to around $30 \%$ which is partly the result of greater Tesco involvement in product design and a major category-by-category redesign of packaging led by a seconded UK executive ${ }^{4}$. These changes progressed alongside greater formalisation of logistical processes in the form of increased "store ready" merchandising which is helping to reduce the labour cost of replenishment (SHORE CAPITAL, 2010a).

Complementing the own label ranges that are transferred from the wider Tesco business, the Asian operations also benefit from brand extensions into new product areas that have proved successful elsewhere. With research suggesting that Tesco customers who use its retailing services spend four times as much in store than those who do not (RBS, 2009), it makes sense to develop additional services and capitalise on this loyal tranche of consumers. The more developed Asian operations such as the South Korean business have mirrored the UK with entry into Telecom services through mobile phone sales and financial services since 2003. This approach has also been seen more widely across the Asian business, as has the approach to online sales fulfilment, initially via stores rather than dedicated warehouses, given that costs broadly move in line with revenues.

The successful Clubcard loyalty scheme is increasingly leveraged across 12 of Tesco's international operations, with South Korea attaining the highest Clubcard sales penetration throughout the global business. While this relationship marketing tool cost $£ 10 \mathrm{~m}$ to initially develop in the UK, the cost of implementing it internationally is just $£ 500,000$ per country (SHORE CAPITAL, 2011). Important in providing customer rewards for continued behavioural loyalty, the scheme is also significant in delivering information relating to customer behaviour (HUMBY et al., 2008). Such understanding of customers is further reinforced by leveraging the expertise of Tesco's 100\% owned subsidiary, DunnHumby, a customer insight firm, that supports international operations from market entry through incountry expansion. 
Softer competencies such as the Tesco "Values" of "Every Little Helps" and the corporate steering wheel - a strategic management tool based on KAPLAN and NORTON's (1996) balanced scorecard - are also extended beyond the home market. Unsurprisingly, LOWE et al. (2012, p 17) argues that the transference of the Tesco Operating Model moves beyond issues of efficiency and cost saving and becomes central to developing the organizational culture of Tesco across national borders 'by providing greater shared meaning in how and what gets done'. There are consequently an array of competencies that have been transferred from the firm to the region - as seen most successfully in South Korea which is seen as the blueprint of transference (see Figure 2)

Figure 2 about here

\section{THE REGION IN THE FIRM (LOCALIZATION AT THE NATIONAL AND SUB- NATIONAL SCALES WITHIN ASIA, AND SUBSEQUENT KNOWLEDGE TRANSFERS)}

In this section we assess the degree to which the region infiltrates the practices of the retail firm within and across Asia and how these newly learned regional capabilities may then be leveraged elsewhere across the international business. This is important as strategically and operationally the centre ceases to be the "command and control" focus, with different forms of knowledge originating from (and passed between) international retail subsidiaries. While centralization and standardization imperatives, particularly of back office and non-customer facing operational functions, are critical, it is necessary for Tesco to strategically localize to the environments within which it locates as 'each market is different and it cannot simply import tried and tested formats elsewhere into a very distinctive arena' (SHORE CAPITAL, 2007, p $54)$.

\section{Store formats and regulatory adaptation}

Localization is seen across a range of customer-facing competencies, partly as a function of the different cultures of consumption within which the organization finds itself ( $c f$. JACKSON, 2004). Most obviously this has been seen in retaining the Homeplus nameplate on operations in South Korea and the Tesco Lotus fascia in Thailand rather than running exclusively with a "foreign" Tesco identity. More meaningfully, the store proposition is carefully tailored to the individual market, which is something important given consumer resistance to "developed" formats in some parts of Asia and elsewhere (e.g. GOLDMAN et al., 2002; RODRÍGUEZ et 
al., 2002). For example, in Thailand, where customers are used to using local wet markets rather than hypermarkets, there has been substantial modification to store design including fresh food sold in loose or small quantities so that customers can feel closer to the produce, given consumer hesitation to purchase fresh produce in "developed" retail formats $(c f$. HUMPHREY, 2007). In addition, the number of shopfloor staff has been slightly increased in order to mimic - to some degree - the interaction customers are used to in their traditional daily shopping experiences. Wholly new store formats have been developed such as the $10,000 \mathrm{sq} \mathrm{ft}$ "Talad" format in Thailand in 2006. The store interior is split into two spaces: the "store area" offers 4,500 product lines with $80 \%$ of the merchandise made up of consumer products and fresh foods, with the remainder clothing, hardware and a few electrical appliances; and a "mall area" comprising of small shops, such as bookstores, drugstores and opticians. By 2012, this format had expanded to 105 stores, yet its design has evolved over time, informed by customer feedback and knowledge relating to operations, merchandising and competition.

Localization through format diversity is also important in mitigating against the effects of regulatory challenge. As COE and HESS (2005, pp. 460) note, retail market entry may result in a 'changing regulatory stance of the governments in those countries', due to lobbying by domestic firms that have detrimental effects on new market entrants (COE and WRIGLEY, 2007). This may take the form of changing retail planning regulations, restrictions on further inward investment or tighter competition policy which requires further adaptation by the internationalizing retailer (MUTEBI, 2007). Conversely, retail TNCs are likely to have themselves been active agents in lobbying for favourable regulations, though these interactions and their effects are particularly difficult to identify given their essentially secretive nature (SPARKS, 2008). In these complex ways then, 'transnational retailers are not simply institution takers; rather, they contribute actively to influencing institutional change in the host economies they enter' (DURAND and WRIGLEY, 2009, p. 1551-2). In Asia, between the economic crisis of 1997/8 and the early 2000s, large format retailers competed in fairly unregulated markets. This permitted the development of strong hypermarket portfolios across many Asian countries, though the late 1990s and early 2000s saw a series of regulatory interventions in response to concerns over the effects of large format retailers on indigenous operators and the desirability of TNC driven retail change. Regulations tightened across Asia, affecting FDI, competition and fair trade and land use zoning policies though there were differences between countries. For example, in Thailand, Tesco faced an array of tightened regulations, notably: 
- Trade Competition Act (1999) - tightened regulation against anti-competitive business activities and market dominance.

- Foreign Business Act (effective 2000) which replaced the older Alien Business Law restricted foreign participants in certain types of business (including retail) - but these restrictions were lifted if minimum capital requirements were met.

- Zoning Laws - which were progressively tightened - initially in 1999/2000 to control development in Bangkok, and then in 2003 to control development in secondary 'up country' cities and towns.

- Store Opening Hours regulation - effective from 2004 to limit stores over $300 \mathrm{sq}$ metres to 11 trading hours per day.

In the short term, Tesco pursued rapid pre-emptive development site acquisition in Bangkok in the face of prospective zoning tightening. Over the longer term, regulatory tightening demanded agile adaptation from the standardized hypermarket model and a shift from the unidirectional transference of knowledge and competencies from the home market. In part this adaptation owed a great deal to initiatives in the UK circumventing land-use planning regulation through the development of small format skills with the introduction of a small convenience format, Tesco Express ( $c f$. WOOD et al., 2010). While this knowledge was transferred to Thailand, it was then further refined within the region, and considerable operational knowledge flowed back to the UK home market and elsewhere. Tesco Lotus began infilling the hypermarket network in Bangkok with the small Tesco Lotus Express convenience stores (c. 3,200 sq. ft.) at a considerable pace. At the end of 2002, there were only 9 such stores. By the end of 2004, this had growth to 47 . This trend has since continued with the number of smaller stores standing at 1,284 cf. 149 hypermarkets at the end of 2012/13.

\section{Localizing organizational culture}

The symbiotic relationship between the region and the firm is evident in the evolution and management of the organizational culture of the retail subsidiary. As SCHOENBERGER (1999) testifies, units and divisions within the wider global firm develop their own identities and ways of thinking and working given their situational specificities and cultural embeddedness. To address this potentially divisive and destabilising issue, there have been conscious efforts to foster a hybrid philosophy at Samsung-Tesco in South Korea, for example.

Figure 3 presents what has been labelled a "synbaration" culture within the retail subsidiary that attempts to offer a fusion of the synbaram culture ('excitement' in Korean) (the East) with 
an apparent rationalism of the West - something LEE (2011, p 34) suggests aims 'to provide a pleasant working environment for employees to become a professional in their major areas, and to create a phenomenon for them to balance their work and family life'. Consequently, there is a focus on a CSP culture (customer-focused, synbaram and professional) that blends the "Western rational processes", such as "talent spotting" for employee development (imported from elsewhere in the firm) and an analytical, knowledge-based approach in store operations with the Eastern values of relationships, group working and team spirit, with the retailer operating, for example, 250 staff hobby clubs. This cultural blend has been regarded as highly successful and is repeatedly referred to whenever Samsung-Tesco President Seong Han Lee comments on the foundations of success in the business.

Figure 3 about here

\section{Organizational structures underpinning knowledge \& capability flows}

The association between the firm and the region clearly represents a dialectical relationship with individual country businesses operating as quasi-independent subsidiaries - something characterized as 'locally focused but internationally supported' (NOMURA CAPITAL, 2009, p 37). It is notable that the level of Tesco expatriate presence in-country is limited, with only 9 executives from the UK business present in the Samsung-Tesco (South Korean) business that has over 23,000 employees (TESCO PLC, 2011). However, a degree of arm's length control is maintained, with each country incentivised across a broad range of hard financial targets and customer satisfaction metrics. Major capital expenditure requires home market approval: for example, new store development is considered at a monthly meeting of the UK-based Property Acquisition Committee (PAC) through video-conferencing, where proposals are scrutinised by a selection of senior board directors who frequently visit the international businesses and gain knowledge of the markets.

Similar top-down monitoring is executed through the Tesco International Support Office, a function that has emerged over the past decade, consisting of highly mobile teams of 'knowledge activists' or organizational translators ( $c f$. GERTLER, 2003) transferring best practice into four critical areas of retail marketing and management: Retail Skills; Commercial Sourcing \& Capabilities; Marketing \& Consumer Focus Team and the Human Resources Team. There is also a separate top-down co-ordination of finance and supply chain functions centred 
around the International Finance Director and International Supply Chain Director (see Figure 4).

Figure 4 about here

While the influence of the firm in the region is critical to successful and efficient retail execution, we have recognized the flow of capabilities that have originated at (and streamed from) the Asian businesses. Clearly, capturing these 'bottom-up' sources of knowledge is challenging. Because large, dispersed, but locally embedded store networks in different parts of a retail TNC inevitably develop different organizational capabilities and interpretive frameworks, it is vital that knowledge generated from these communities of practice is captured, then transferred and translated within intra-firm networks ( $c f$. CURRAH and WRIGLEY, 2004; WOOD and REYNOLDS, 2012a). As both PALMER and QUINN (2005) and JONSSON (2008) note, it is essential that there is both a 'degree of learning' evident in the ability to adopt and adhere to the acquired learning and also a 'locus of learning diffusion', which relates to how the knowledge is coordinated and diffused within the organization. Similarly AMBOS et al. (2006, p 308) recognise a concern that valuable knowledge generated within international business subsidiaries could be ignored because it slips 'through headquarters' filters'. There is significant evidence in Tesco of attempts to capture this local expertise via shared learning groups at all levels of organization, right though to the Asian Leaders shared learning group (including country CEOs) and to the higher level group involving the Chairman, Central Europe region CEO, Director of International Sourcing, CEO of Thailand (and Regional Asia CEO) and CEO of South Korea. Perhaps understandably, these mechanisms appear to be less formalized than the processes in place for ensuring standardization of execution (such as the Tesco Operating Model).

A key transferable competency that Tesco has leveraged in all of its host markets has been its industry-leading expertise in site research and property appraisal (TACCONELLI and WRIGLEY, 2009) - something critical in international retail expansion and the realisation of territorial embeddedness (WOOD and REYNOLDS, 2012b). Initially sending expatriates, the retailer has quickly developed local, fully trained analyst teams - a 'decolonization' trend known to be important in successful localization (FRYXELL et al., 2004). For example, in China Tesco, a 30-strong team of site researchers follow a systematic procedure for network planning that prioritises cities for development, identifies districts within those cities, and then 
specific sites (see Table 6). Tesco has been able to resource these property functions with executives that have a background in interpreting data-poor and particularistic markets, which provides significant insight compared to many other international retailers.

Table 6 about here

\section{Spatially variegated format and expansion strategies}

Not only does Tesco's Asian expansion provide evidence of partial localization for individual countries, it also exhibits a capability to fundamentally redesign expansion strategies according to specific host market circumstances and - when necessary - an ability to shape its management and formats for particular sub-national regional variations. For example, in Thailand, Tesco Lotus has also been innovative in adopting sub-national localization to circumvent tightening development control in low-income 'up-country' towns by developing a low-build cost ( $£ 3$ million per store) "Value" format offering 21,500 product lines. The smallscale (35,000 sq ft) core is surrounded by a local fresh food vendor market (leased space) and farming supplies/demonstration areas. There is also a heavy emphasis on the local sourcing of products. The format has expanded modestly from 11 units at the end of 2004, to 36 in 2012.

A more wide-ranging departure from Tesco's established expansion strategy came in response to specific host market conditions in China. Aware that many of the strategic retail locations within prime, so-called Tier 1 cities have already been taken by competitors, there has been a conscious shift in focus to Tier 2 and 3 cities where Tesco aims to secure strategic key locations within growing major city catchments (TOWLE, 2010). The strategy evolved to specifically focus on hypermarket development situated within shopping malls that exhibit high degrees of retail gravity and robust levels of customer footfall. However, the retailer found that leasehold sites for such hypermarkets were often situated in poor quality malls, while in many Tier 2 and 3 cities suitable malls for leasehold hypermarkets did not yet exist (WALLER, 2010). Therefore, while there remains a focus on developing leasehold hypermarkets within third party mall developments where high quality space is available, the retailer has found that in order to ensure that it became the prime "anchor" store, it has often been necessary that Tesco itself leads these overall projects to develop the freehold malls that are anchored by a Tesco hypermarket. This has the potential to also generate real estate earnings from mall income and management fees and also to deliver returns from asset appreciation. Nevertheless, such significant undertakings do not come without significant risk. 
First, given that these developments are outside of the Tier 1 cities, consumption habits are less established and income per capita is lower, especially within the Tier 3 cities - more positively however, land prices are lower and many still have populations in excess of 1 million 'so it's not like going to frontier territory' (BOAML, 2010, p 24). Second, there are considerable cost implications of moving from becoming a "hypermarket operator" to a "major mall developer with hypermarket operations". As a retailer that has historically been lauded for its capital discipline, this represents a considerable challenge - something BOAML neatly summarized in 2010:

Going down the mall route may give Tesco access to the prime site in each city ... but it comes at a high capital cost. With each mall costing c£50-60m to build... its ambition to open 80 malls in the next 5 years would cost $£ 4-5$ bn.... Given Tesco, in total, only spends $£ 1.5 \mathrm{bn}$ pa in international markets, it cannot afford to spend $£ 1 \mathrm{bn}+\mathrm{pa}$ in China, alone, even before the logistical and administrative considerations are taken into account.

To partly overcome these cost implications, Tesco established a joint venture property organization specifically focused on mall development that is itself regionally focused, and so mirrors the structure of the wider Chinese retail business (see next section). Tesco China Property Company (TCPCo) is a $£ 170 \mathrm{~m}$ venture, funded by $£ 30 \mathrm{~m}$ of equity from Tesco, $£ 30 \mathrm{~m}$ from a consortium of Asian investors and debt provided by banks including Standard Chartered and the Commercial Bank of China (FINANCIAL TIMES, 2011). The use of such joint venture partners provides scope to respond quickly to secure prime development sites and to build the retail and mall brand across the regions. However, it does not simply represent a strategy of mitigating capital exposure on these costly projects but is itself an attempt to deepen the localization and embeddedness process. Investors bring with them endorsement of the business plan and can provide advice and contacts in the locality both in commerce but also allimportant political officials - something known to be especially important within such a 'particularistic' market (WOOD and REYNOLDS, 2012b). The use of a property joint venture organization also supports cost and quality control of the development schemes, and allows the development of a tailored mall format that Tesco believes will be attractive in the regions and particularly benefit the hypermarket anchor. The mid-market "Lifespace" mall format is a circa. 500k sq ft development, anchored by a circa. 100k sq ft Tesco hypermarket positioned in a prominent location at the heart of the mall on two levels (McLLWEE, 2010). 
Stores developed within these malls are localized with a food range that includes reptiles and amphibians and attuned to local customer demands. While there were elements of modernisation in that carcasses are located behind the counters rather than the aisles, butchery still takes place in front of the customers. In addition, dumplings and pancakes and other local lines provide elements of retail theatre. Nevertheless, the conventional Tesco model is in evidence with the familiar "power aisle" running through the store, meat is organized on a 'good, better, best' pricing structure and sub-brands such as F\&F apparel lines are a prominent feature (SHORE CAPITAL, 2010a). Elements of the transferable Tesco model are also seen with Clubcard introduced to the Chinese market and experiencing a $70 \%$ sales participation which provides representative real-time data on customer behaviour, with Tesco subsidiary, dunnhumby involved in the analysis. Other imported non-customer-facing capabilities include business appraisal processes, namely the Tesco Brand Review \& Customer Plan and the leveraging of some central capability to manage brand, concepts and marketing plans, though these are executed by local marketing teams (WALLER, 2010).

\section{Sub-national regional management in China}

Tesco's evolving strategy in China has specifically demanded a degree of sub-national regional sensitivity rarely required in more modestly sized host countries. While the retailer's entry into China was facilitated through a partnership with an existing operator that exhibited many aspects of the classic transference approach discussed earlier ${ }^{5}$, a uniform national strategy for the country proved inappropriate with sub-national variation in organization and execution required. Particularly relevant to consider in expansion within China is the sheer scale of the market, with local and regional contexts that may be quite distinct from any national conditions (cf. MEYER et al., 2011; CHANEY and GAMBLE, 2008).

Tesco found that co-ordinating its activities centrally was inappropriate - similarly many of its leading suppliers such as Coca Cola are themselves regionally managed. As HUTZSCHENREUTER et al. (2011) discuss in the context of MNC expansion, some of the resource constraints that the firm can experience are managerial. Tesco has addressed this concern by focusing management and concentrating store development focus on specific subnational regions. The degree of in-country localization was made clear recently:

Even within a single region temperatures, tastes and preferred brands can all vary, so our operation is 'local' in many ways. For example, our buying teams are based in different regions and even in specific provinces and cities to be close to our customers and suppliers. 
We have appointed more local Directors this year to strengthen our China Board and have ongoing plans to recruit and develop local talent (Tesco Annual Report, 2012)

Of course, such intra-country variation in the product offer is taken for granted in home market settings, where local or regional merchandise is typically offered (RICKETTS HEIN et al., 2006). This sensitivity to regional differences within a host country emphasizes the desire to achieve true multi-scalar embeddedness. Departing from what was previously described as 'a scatter gun approach' to development (BOAML, 2010, p 23), Tesco China moved to focus on three regions (the North, around Beijing; East, around Shanghai; South, around Guangzhou) with three fully accountable regional managing directors (see Table 7). In each of these regions, the retailer has established a management structure (complete with buying teams) and built three regional food distribution centres to consolidate supply and logistics 'to improve the speed to store, store goods-receipt labour efficiency and product freshness (reduced shrink and better quality impression)' (BOAML, 2010, p 23).

Table 7 about here

The reasons for a focus on these three particular sub-national regions are clear: first, they are relatively populous $(750 \mathrm{~m})$ and affluent, with GDP per capita of 2-3 times the national average. Indeed, Tesco suggest that the coastal region in Eastern China constitutes about $15 \%$ of its territory, yet contributes $60 \%$ of the country's economy (CHINA CHAIN STORE \& FRANCHISE ASSOCIATION, 2011). Second, the top five food retailers currently account for just $£ 20$ bn sales in these regions, which offer significant potential to capitalise on income growth and the transition to "modern" forms of food retailing (BOAML, 2010). While the initial expansion plans of Tesco in China have recently been scaled back following a business review $^{6}$, the case underlines the requirement for a sub-national regional focus to respond to a constantly evolving balance between the firm's transferable competencies and the localization demanded across its uneven geography. This is summarized in Table 8.

Table 8 about here

\section{CONCLUSION}

This paper has examined the Asian expansion of UK food retailer, Tesco, in order to explore the multi-scalar aspects of capability transference and localization that have relevance for debates within economic geography and international business and marketing management. 
By utilising privileged access to a knowledge network of equity analysts who conduct ongoing longitudinal analysis of the retailer and wider sector, we have explored how Tesco balances the localization demands of subsidiaries embedded within their own national and sub-national regional contexts, with the efficient and proven transference of capabilities from the centre.

We have examined how the retailer is able to formulate (but not insist on the application of) a range of "off the shelf" transferable competencies and capabilities such as "blueprint" principles, the Tesco Operating Model ("Tesco in a Box"), distribution centre and supply chain approaches, tiered sub-brand/private labels, aligned financial services and relationship marketing tools (Clubcard loyalty scheme) that can be leveraged, at least to some degree, within most institutional contexts, given their limited sensitivity to different customer cultures and their back office efficiency generation. In the process, we have demonstrated how the degree of knowledge transfer successfully applied from the centre to the subsidiary is, in part, governed by the conditions inherent within the host market (e.g. competition, consumer cultures, regulatory frameworks, sophistication of supply networks).

While the research literature acknowledges that a binary distinction between the two forces of localization and centralization could result in inertia and inefficiency (in the event of wholesale devolvement to local decision making) or an insensitivity to local circumstances (in the case of tight, centralized control) (FIGUEIREDO, 2011), our paper has provided evidence of the importance of 'hybridization' in action. In numerous instances, the transfer of the "Tesco model" was partial within national subsidiaries and there was subsequent localization of store formats, product ranges, services and organizational culture. In some markets, wholly new strategies were required and significantly departed from the accepted Tesco approach, due to a wide variety of cultural, institutional or regulatory driving factors. Such localization offers the potential for learning and subsequent knowledge flow from the subsidiary to the centre as well as the more accepted route from the centre to the subsidiary. Such conditions were especially evident in Tesco's South Korean and Thai businesses, which have taken expertise from the established Tesco international operating model, amended those strategies in the host market, and channelled some of that expertise back to influence operations in the core UK and wider international business.

But moreover, the paper has provided evidence that the hybridization process not only varies between national subsidiaries, but also that there may be sub-national regional variation in 
terms of the mediation between transference and strategic localization. Such multi-scalar adaptation has most clearly been seen in the early development of Tesco's operations within China, where sub-national regional organizational structures are required to manage sourcing, supply chain and store operations given the substantial differences in climate, income and culture within a single country. Importantly, such a locally sensitive approach does not necessarily represent excessive localization, as the subsidiary continues to benefit in large part from the operating model of the wider retail organization. Instead, it represents efforts to apply appropriate strategies and capabilities where they are perceived as necessary. Of course, this careful approach by no means guarantees success. Continued adaptation is likely to be necessary as expansion into developing retail environments continues to exhibit high risk opportunities; yet responding to the nuances of national and sub-national regions surely increases the likelihood of realizing appropriately territorially embedded retail operations.

\section{ENDNOTES}

${ }^{1}$ The use of the term embeddedness within economic geography is not without its critics. Andrew JONES (2008) recently argued that the expression's usefulness is limited due to its under-emphasis of the relational nature of power and agency, resulting in a limited conceptualization of the spatial development of economic activity.

2 Tesco had previously acquired a food retail business in Ireland (The Three Guys chain) in 1979.

3 'The planogram is a blueprint of the store display case and considers shelf management and presentation of each product. Specifically, the planogram design takes into account shelf space allocation and location of each product to maximize store sales and profits' (CHUNG et al., 2007, p 585).

${ }^{4}$ Many thanks to an anonymous referee for clarifying these issues.

${ }^{5}$ In common with its accepted expansion mode, in 2004 Tesco entered China through a partnership with Ting Hsin owned local operator, Hymall, acquiring $50 \%$ of 25 hypermarkets for $£ 148 \mathrm{~m}$, followed with the purchase of a further $40 \%$ for $£ 181 \mathrm{~m}$ in December 2006 . In some respects the approach to expansion has been along the lines of the established Tesco approach within Asia. The retailer acquired a share in a small hypermarket retailer and then increased that stake, having learned a great deal about the market. Elements of the Operating Model were introduced and, in March 2007, a new fresh food distribution centre was opened in Shanghai to supply 30 stores in Shanghai, Jiangsu province and Zhejiang province. Operationally this was important to gain control of the distribution network and therefore ensure food quality. Having traded initially as "Happy Shopper" through the Hymall joint venture, a period when those original stores were refitted, there was a focus on mediating between 
the tendencies of transference and localization in store design, a greater focus afforded to the Tesco fascia and the gradual introduction of the pillar Tesco sub-brands across the product offer.

${ }^{6}$ In 2010, development plans for the Chinese business were ambitious with 600 'ideal' locations identified across 90 cities and expectations by 2014/15 of 50 malls trading (each with a hypermarket); 30 malls in development and over 150 leasehold hypermarkets (WALLER, 2010). Despite these ambitious plans, Tesco's strategy for China has been significantly scaled back since the writing of this paper. By 2013, the retailer's Chinese business was estimated to be losing in the region of $£ 50 \mathrm{~m}$ per annum (SHORE CAPITAL, 2013) and analysts widely doubted its continued viability. In August 2013, the retailer unsurprisingly signalled a new 'capital light' strategy for China, consisting of a joint venture with China Resources Enterprise (CRE), a state controlled retailer, ranked 2nd largest in China with coverage in 24 of its 34 provinces. Tesco argued this offered a route to growth that prevented it from over-extending its capital commitments, with a 20/80 ownership split in favour of CRE. In addition, the joint venture would create a market leading grocery retailer with sales in excess of current market leader, RT Mart/Auchan. 


\section{REFERENCES}

ABERNATHY F. H., VOLPE A. and WEIL D. (2006) The future of the apparel and textile industries: prospects and choices for public and private actors, Environment and Planning A 38, 2207-32.

ALMEIDA P. and PHENE A. (2004) Subsidiaries and knowledge creation: the influence of the MNC and host country on innovation, Strategic Management Journal 25, 847-64.

AMBOS T. C., AMBOS B. and SCHLEGELMILCH B. B. (2006) Learning from foreign subsidiaries: An empirical investigation of headquarters' benefits from reverse knowledge transfers, International Business Review 15, 294-312.

AMIN A. and COHENDET P. (2004) Architectures of Knowledge. Firms, Capabilities, and Communities. Oxford University Press, Oxford, UK.

ANDERSSON U. and PAHLBERG C. (1997) Subsidiary influence on strategic behaviour in MNCs: an empirical study, International Business Review 6, 319-34.

ANDERSSON U., FORSGREN M. and HOLM U. (2007) Balancing subsidiary influence in the federative MNC: a business network view, Journal of International Business Studies 38, 802-18.

BANK OF AMERICA MERRILL LYNCH (BOAML) (2010) Upgrade to Buy, 490p PO getting its mojo back, Bank of America Merrill Lynch, 10 September.

BANK OF AMERICA MERRILL LYNCH (BOAML) (2011) Tesco: Tough macro but genuine signs of promise - Buy reiterated, Bank of America Merrill Lynch, 27 June.

BARCLAYS CAPITAL (2012a) TESCO Margins: More clarity, but less upside, European Food Retail, 18 April 2012.

BARCLAYS CAPITAL (2012b) TESCO Fill the picture, European Food Retail, 17 May 2012. 
BARTLETT C. A. and GHOSHAL S. (1989) Managing Across Borders. Harvard University Press, Boston, MA.

BIANCHI C. C. and ARNOLD S. J. (2004) An institutional perspective on retail internationalization success: Home Depot in Chile, International Review of Retail, Distribution \& Consumer Research 14, 149-69.

BIRKINSHAW J. and HOOD N. (1998) Multinational subsidiary evolution: capability and charter change in foreign-owned subsidiary companies, The Academy of Management Review 23, 773-95.

CHANEY I. and GAMBLE J. (2008) Retail store ownership influences on Chinese consumers, International Business Review 17, 170-83.

CHINA CHAIN STORE \& FRANCHISE ASSOCIATION (CCFA) (2011) Tesco Continues Expansion Though Hit Hard. Accessed at http://www.chinaretail.org/shownews.asp?id=2321

CHINI T. C. (2004) Effective Knowledge Transfer in Multinational Corporations. Palgrave MacMillan, Basingstoke, Hampshire.

CHUNG C., SCHMIT T. M., DONG D. and KAISER H. M. (2007) Economic evaluation of shelf-space management in grocery stores, Agribusiness 23, 583-97.

CLARK G. (1998) Stylized facts and close dialogue: methodology in economic geography, Annals of the Association of American Geographers 88, 73-87.

CLARK G. L. (2007) Beyond close dialogue: economic geography as if it matters, in TICKELL A., SHEPPARD E., PECK J. and BARNES T. (Eds) Politics and practice in economic geography, pp. 187-98. Sage, London.

COE N. and HESS M. (2005) The internationalization of retailing: implications for supply network restructuring in East Asia and Eastern Europe, Journal of Economic Geography 5, 449-73. 
COE N. and LEE Y.-S. (2006) The strategic localization of transnational retailers: the case of Samsung-Tesco in South Korea, Economic Geography 82, 61-88.

COE N. M. and LEE Y.-S. (2013) 'We've learnt how to be local': the deepening territorial embeddedness of Samsung-Tesco in South Korea, Journal of Economic Geography 13, 327-56.

COE N. and WRIGLEY N. (2007) Host economy impacts of transnational retail: the research agenda, Journal of Economic Geography 7, 341-71.

COHEN W. M. and LEVINTHAL D. A. (1990) Absorptive capacity: a new perspective on learning and innovation, Administrative Science Quarterly 35, 128-52.

CURRAH A. and WRIGLEY N. (2004) Networks of organizational learning and adaptation in retail TNCs, Global Networks 4, 1-23.

DAWSON J. A. (2007) Scoping and conceptualising retailer internationalisation, Journal of Economic Geography 7, 373-97.

DAWSON J. A., LARKE R. and CHOI S. C. (2006) Tesco: Transferring marketing success factors internationally, in DAWSON J. A., LARKE R. and MUKOYAMA M. (Eds) Strategic Issues in International Retailing, pp. 170-95. Routledge, Abingdon, Oxfordshire.

DAWSON J. A. and MUKOYAMA M. (2014) Building international strategy with formats and formulae, in DAWSON J. A. and MUKOYAMA M. (Eds) Global Strategies in Retailing. Asian and European Experiences, pp. 37-54. Routledge, London.

DICKEN P. (2000) Places and flows: situating international investment, in CLARK G., FELDMAN M. P. and GERTLER M. S. (Eds) The Oxford Handbook of Economic Geography, pp. 275-91. Oxford University Press, Oxford, UK.

DICKEN P. (2003) 'Placing firms': grounding the debate on the 'global' corporation., in PECK J. and YEUNG H. W. C. (Eds) Remaking the Global Economy: Economic-Geographical Perspectives, pp. 27-44. SAGE Publications, London. 
DURAND C. (2007) Externalities from foreign direct investment in the Mexican retailing sector, Cambridge Journal of Economics 31, 393-411.

DURAND C. and WRIGLEY N. (2009) Institutional and economic determinants of transnational retailer expansion and performance: a comparative analysis of Wal-Mart and Carrefour, Environment and Planning A 41, 1534-55.

FIGUEIREDO P. N. (2011) The role of dual embeddedness in the innovative performance of MNE subsidiaries: evidence from Brazil, Journal of Management Studies 48, 417-40.

FINANCIAL TIMES (2011) Tesco pushes further into China, Financial Times, February 28.

FRANZ M. (2010) The role of resistance in a retail production network: Protests against supermarkets in India, Singapore Journal of Tropical Geography 31, 317-29.

FRANZ M. (2012) Resistance and strategic responses in food supply networks: Metro Cash \& Carry in Bangalore, Geografiska Annaler: Series B, Human Geography 94, 161-76.

FRYXELL G. E., BUTLER J. and CHOI A. (2004) Successful localization programs in China: an important element in strategy implementation, Journal of World Business 39, 268-82.

GAMBLE J. (2010) Transferring organizational practices and the dynamics of hybridization: Japanese retail multinationals in China, Journal of Management Studies 47, 705-32.

GERTLER M. S. (2003) Tacit knowledge and the economic geography of context, or The undefinable tacitness of being (there), Journal of Economic Geography 3, 75-99.

GOLDMAN A., RAMASWAMI S. and KRIDER R. E. (2002) Barriers to the advancement of modern food retail formats: theory and measurement, Journal of Retailing 78, 281-95.

GUSTAFSSON K., JONSON G., SMITH D. and SPARKS L. (2009) Retailing Logistics \& Fresh Food Packaging: Managing Change in the Supply Chain. Kogan Page, London. 
HENNART J. F. (2009) Down with MNE-centric theories! Market entry and expansion as the bundling of MNE and local assets, Journal of International Business Studies 40, 1432-54.

HIGGINSON, A. (2008) Tesco in Asia. Presentation at Tesco Asia Analyst Field Trip, November 2008.

HUTZSCHENREUTER T., VOLL J. C. and VERBEKE A. (2011) The impact of added cultural distance and cultural diversity on international expansion patterns: a Penrosean perspective, Journal of Management Studies 48, 305-29.

HUMBY C., HUNT T. and PHILLIPS T. (2008) Scoring Points: How Tesco Continues to Win Customer Loyalty Kogan Page, London.

HUMPHREY J. (2007) The supermarket revolution in developing countries: tidal wave or tough competitive struggle?, Journal of Economic Geography 7, 433-50.

HURT M. and HURT S. (2005) Transfer of managerial practices by French food retailers to operations in Poland, The Academy of Management Executive 19, 36-49.

JACKSON P. (2004) Local consumption cultures in a globalizing world, Transactions of the Institute of British Geographers 29, 165-78.

JONES A. (2008) Beyond embeddedness: economic practices and the invisible dimensions of transnational business activity, Progress in Human Geography 32, 71-88.

JONSSON A. (2008) A transnational perspective on knowledge sharing: lessons learned from IKEA's entry into Russia, China and Japan, International Review of Retail, Distribution \& Consumer Research 18, 17-44.

JONSSON A. and FOSS N. J. (2011) International expansion through flexible replication: Learning from the internationalization experience of IKEA, Journal of International Business Studies 42, 1079-102. 
JP MORGAN CAZENOVE (2011) Tesco: Try Something New Today - More Reasons to Buy Tesco. Europe Equity Research, 19th July.

KAPLAN R. S. and NORTON D. P. (1996) Using the balanced scorecard as a strategic management system, Harvard Business Review 74, 75-85.

LEE, S. H. (2010) Tesco in Asia 2010: Homeplus - A World Class Business. Presentation at Tesco in Asia Analyst Field Trip 2010, 21st-23rd November.

LEE Y.-T. (2011) Competing on entrepreneurial management innovation: The fact-based mangement system of HOMEPLUS, The Journal of Creativity and Innovation 4, 1-48.

LOWE M. and WRIGLEY N. (2010) The 'continuously morphing' retail TNC during market entry: interpreting Tesco's expansion into the USA, Economic Geography 86, 381-408.

LOWE M., GEORGE G. and ALEXY O. (2012) Organizational identity and capability development in internationalization: transference, splicing and enhanced imitation in Tesco's US market entry, Journal of Economic Geography 12, 1021-54.

McLlWEE, L. (2010) Tesco in Asia - key messages. Presentation at Tesco in Asia Analyst Field Trip 2010, 21st-23rd November.

MEYER K. E., MUDAMBI R. and NARULA R. (2011) Multinational enterprises and local contexts: the opportunities and challenges of multiple embeddedness, Journal of Management Studies 48, 235-52.

MORGAN G. (2001) Transnational communities and business systems, Global Networks 1, 113-30.

MUDAMBI R. and NAVARRA P. (2004) Is knowledge power? Knowledge flows, subsidiary power and rent-seeking within MNCs, Journal of International Business Studies 35, 385-406.

MURPHY, M. (2008) Tesco in Asia 2008: Leveraging Scale - Asia Joint Buying Team. Presentation at Tesco Asia Analyst Field Trip, November 2008. 
MUTEBI A. M. (2007) Regulatory responses to large-format transnational retail in south-east Asian cities, Urban Studies 44, 357-79.

NOMURA CAPITAL (2009) Tesco: A Group Effort with Strong Growth Ahead, Global Equity Research, Nomura International plc, London, 20 October.

OKEAHALAM C. C. and WOOD S. (2009) Financing internationalisation: a case study of an African retail transnational corporation, Journal of Economic Geography 9, 511-37.

O'NEILL P. (2001) Financial narratives of the modern corporation, Journal of Economic Geography 1, 181-99.

PALMER M. (2004) International retail restructuring and divestment: the experience of Tesco, Journal of Marketing Management 20, 1075-105.

PALMER M. (2005) Retail multinational learning: a case study of Tesco, International Journal of Retail \& Distribution Management 33, 23-48.

PALMER M. and QUINN B. (2005) An exploratory framework for analysing international retail learning, International Review of Retail, Distribution \& Consumer Research 15, 27-52.

PALMER M. and QUINN B. (2007) The nature of international retail divestment: Insights from Ahold, International Marketing Review 24, 26-45.

PHELPS R., ADAMS R. and BESSANT J. (2007) Life cycles of growing organizations: A review with implications for knowledge and learning, International Journal of Management Reviews 9, 1-30.

PRAHALAD C. K. and DOZ Y. L. (1999) The Multinational Mission: Balancing Local Demands and Global Vision. Free Press. 
REARDON T., HENSON S. and BERDEGUE J. (2007) 'Proactive fast-tracking' diffusion of supermarkets in developing countries: implications for market institutions and trade, Journal of Economic Geography 7, 399-431.

REUTERS (2011) Carrefour edges closer to break up as shares slide. Accessed at http://www.reuters.com/article/2011/08/05/us-carrefour-dealtalk-idUSTRE77435M20110805 on 9th August 2011.

RICKETTS HEIN J., ILBERY B. and KNEAFSEY M. (2006) Distribution of local food activity in England and Wales: An index of food relocalization, Regional Studies 40, 289-301.

RODRÍGUEZ E., BERGES M., CASELLAS K., PAOLA R. D., LUPÍN B., GARRIDO L. and GENTILE N. (2002) Consumer behaviour and supermarkets in Argentina, Development Policy Review 20, 429-39.

ROYAL BANK OF SCOTLAND (RBS) (2009) Tesco: 3Q sales preview and beyond, ABN AMRO Bank NV, 4 December.

RUGMAN A., VERBEKE A. and YUAN W. (2011) Re-conceptualizing Bartlett and Ghoshal's classification of national subsidiary roles in the multinational enterprise, Journal of Management Studies 48, 253-77.

RUGMAN A. M. and VERBEKE A. (2003) Extending the theory of the multinational enterprise: internalization and strategic management perspectives, Journal of International Business Studies 34, 125-37.

SALMON W. and TORDJMAN A. (1989) The internationalisation of retailing, International Journal of Retailing 4, 3-16.

SCHOENBERGER E. (1999) The firm in the region and the region in the firm, in BARNES T. and GERTLER M. S. (Eds) The New Industrial Geography: Regions, Regulation and Institutions, pp. 204-25. Routledge, London. 
SHORE CAPITAL (2007) Tesco: Going Global, November 2007, Shore Capital, Equities Research, Bond Street House, 14 Clifford Street, London.

SHORE CAPITAL (2010a) Tesco: Despatches From China and Korea, December 2010, Shore Capital, Equities Research, Bond Street House, 14 Clifford Street, London.

SHORE CAPITAL (2010b) Tesco: The Potential From Immature, Sub-Optimal and Underperforming Capital, October 2010, Shore Capital, Equities Research, Bond Street House, 14 Clifford Street, London.

SHORE CAPITAL (2011) Tesco: The Matrix - the Central European Unit, June 2011, Shore Capital, Equities Research, Bond Street House, 14 Clifford Street, London.

SHORE CAPITAL (2013) Tesco: A New Free Cash Flow Strategy, $6^{\text {th }}$ March 2013, Shore Capital, Equities Research, Bond Street House, 14 Clifford Street, London.

SPARKS L. (2008) When Tony met Bobby, Environment and Planning A 40, 2793-9.

SWOBODA B., ELSNER S. and MORSCHETT D. (2012) Preferences and performance of international strategies in retail sectors: An empirical study, Long Range Planning, in press.

TACCONELLI W. and WRIGLEY N. (2009) Organizational challenges and strategic responses of retail TNCs in post-WTO-entry China, Economic Geography 85, 49-73.

TESCO PLC (1999 - 2011) Tesco Annual Review and Summary Financial Statements 1999 2011 .

TESCO PLC (2012) News Release: Tesco announces property sale and leaseback deal in South Korea. 23 August, 2012. Accessed at http://www.tescoplc.com/index.asp?pageid=17\&newsid=673

TESCO PLC (2013) Philip Clarke speaks at the World Retail Congress in Singapore. Marina Bay Sands, Singapore, 20 March 2013. Accessed at http://www.tescoplc.com/index.asp?pageid=17\&newsid=758 
TOKATLI N. (2008) Global sourcing: insights from the global clothing industry - the case of Zara, a fast fashion retailer, Journal of Economic Geography 8, 21-38.

TOWLE, K. (2010) Tesco in Asia 2010: A Blueprint for Profitable Retailing in China, Presentation at Tesco in Asia Analyst Field Trip 2010, 21st-23rd November.

WALlER, R. (2010) Tesco in Asia 2010: China Property Strategy, Presentation at Tesco in Asia Analyst Field Trip 2010, 21st-23rd November.

WANG F. (2009) Identification of MNC knowledge resources for the local market: an examination of 7-Eleven's international licensing operations, The International Review of Retail, Distribution and Consumer Research 19, 535-51.

WESTPHAL J. D. and CLEMENT M. B. (2008) Sociopolitical dynamics in relations between top managers and security analysts: favor rendering, reciprocity, and analyst stock recommendations, Academy of Management Journal 51, 873-97.

WHITLEY R. (2001) How and why are international firms different? The consequences of cross-border managerial coordination for firm characteristics and behaviour, in MORGAN G., KRISTENSEN P. H. and WHITLEY R. (Eds) The Multinational Firm: Organizing Across Institutional and National Divides, pp. 27-68. Oxford University Press, Oxford, UK.

WINTER S. G. and SZULANSKI G. (2001) Replication as strategy, Organization Science 12, 730-43.

KRISTENSEN P. H. and WHITLEY R. (Eds) The Multinational Firm: Organizing Across Institutional and National Divides, pp. 27-68. Oxford University Press, Oxford, UK.

WOOD S., LOWE M. and WRIGLEY N. (2010) Conceptualising innovative customer-facing responses to planning regulation: the UK food retailers, The Service Industries Journal 30, 1967-90. 
WOOD S. and REYNOLDS J. (2012a) Managing communities and managing knowledge: strategic decision making and store network investment within retail multinationals, Journal of Economic Geography 12, 539-65.

WOOD S. and REYNOLDS J. (2012b) Establishing territorial embeddedness within retail transnational corporation (TNC) expansion: The contribution of store development departments, Regional Studies, DOI:10.1080/00343404.2012.701731

WRIGLEY N. (2000) The globalization of retail capital: themes for economic geography, in CLARK G. L., FELDMAN M. P. and GERTLER M. S. (Eds) The Oxford Handbook of Economic Geography, pp. 292-313. New York and Oxford: Oxford University Press.

WRIGLEY, N. (2005) Transnational retail and emerging markets: what Tesco's experience tells us. Paper presented at the IDS/IIED Conference on Supermarkets and Development, Institute of Development Studies, University of Sussex, October 2005

WRIGLEY N. and CURRAH A. (2003) The stresses of retail internationalization: lessons from Royal Ahold's experience in Latin America, International Review of Retail, Distribution \& Consumer Research 13, 221.

WRIGLEY N., CURRAH A. and WOOD S. (2003) Investment bank analysts and knowledge in economic geography, Environment and Planning A 35, 381-7.

WRIGLEY N., COE N. and CURRAH A. (2005) Globalizing retail: conceptualizing the distribution-based transnational corporation (TNC), Progress in Human Geography 29, 437-57.

ZAINO, J. (2009) The Tesco Directive: Standardize and Innovate, Smart Enterprise Magazine. Accessed at http://www.smartenterprisemag.com/showArticle.jhtml?articleID=217701399 


\section{FIGURES AND TABLES}

Table 1. Embeddedness in Retail TNC Expansion

\begin{tabular}{|l|l|}
\hline $\begin{array}{l}\text { Territorial } \\
\text { embeddedness }\end{array}$ & $\begin{array}{l}\text { How the retail TNC is anchored in different places. Requires the } \\
\text { acceptance across markets and cultures of consumption, planning and } \\
\text { property systems, and logistical and supply chain operations. }\end{array}$ \\
\hline $\begin{array}{l}\text { Societal } \\
\text { embeddedness }\end{array}$ & $\begin{array}{l}\text { Underlines how the cultural, institutional and historical origins of the retail } \\
\text { TNC affect how it operates in new markets. This may relate to supplier } \\
\text { relations, labour-management relations etc. }\end{array}$ \\
\hline $\begin{array}{l}\text { Network } \\
\text { embeddedness }\end{array}$ & $\begin{array}{l}\text { Refers to the composition and structure of network relations of the retail } \\
\text { TNC within and beyond the firm - e.g. with (joint venture) partners, } \\
\text { suppliers, competitors, special interest groups and customers }\end{array}$ \\
\hline
\end{tabular}

Sources: HESS (2004); WRIGLEY et al. (2005); WOOD and REYNOLDS (2012b) 
Figure 1. The Integration-Responsiveness Framework

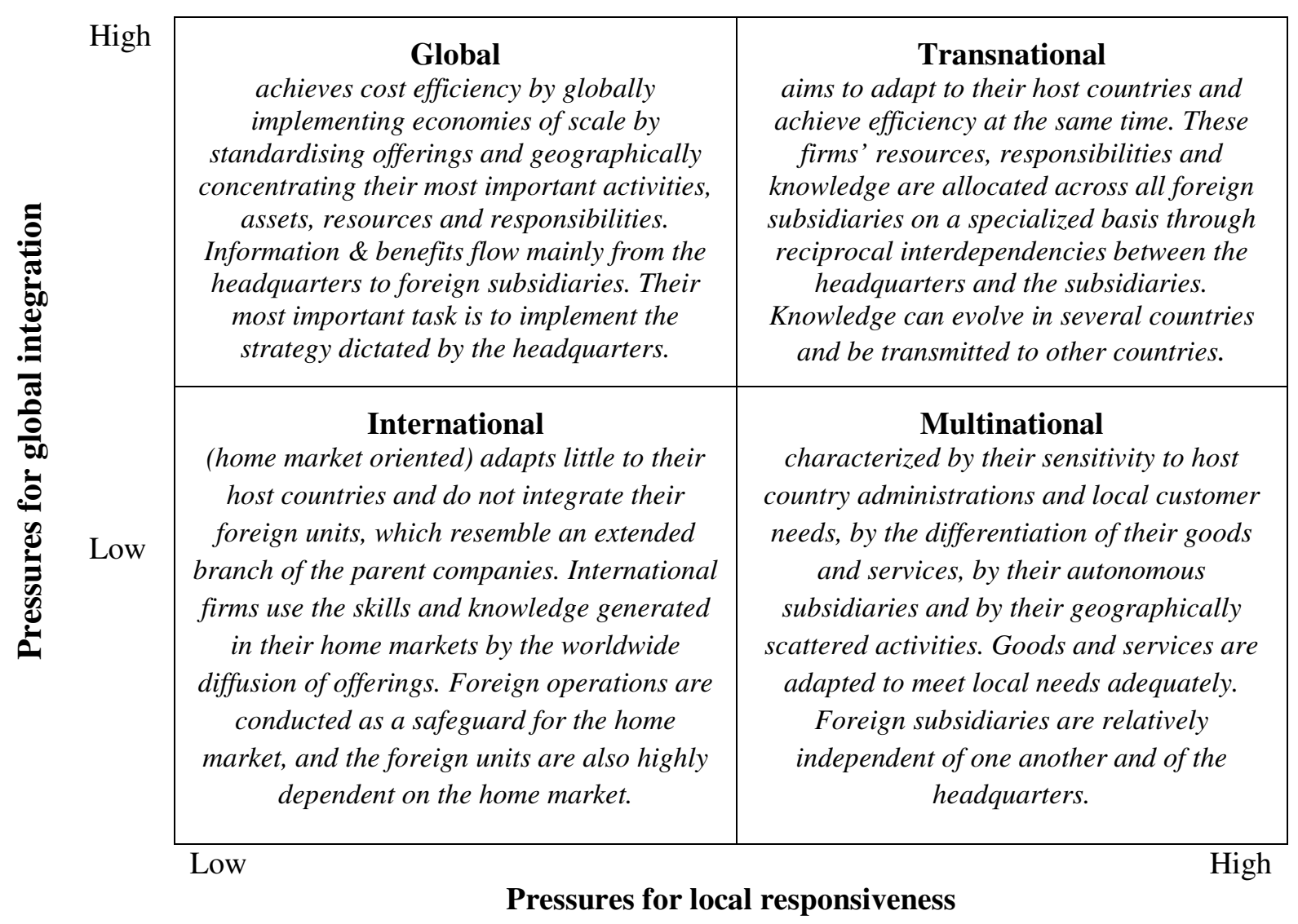

Source: adapted from SWOBODA et al. (2012) drawing on BARTLETT and GHOSHAL (1989); PRAHALAD and DOZ (1987) 
Table 2. Leading Transnational Retailers, Ranked by Sales Outside Home Market, 2010.

\begin{tabular}{|c|c|c|c|c|c|c|c|}
\hline Rank & Name of company & $\begin{array}{c}\text { Country of } \\
\text { origin }\end{array}$ & $\begin{array}{c}\text { International } \\
\text { sales } \\
(\mathrm{US} \$ \mathrm{~m})\end{array}$ & $\begin{array}{c}\text { No. of countries o } \\
\text { f operation } \\
(2010)\end{array}$ & $\begin{array}{c}\text { International sales } \\
\text { (\% of total, } \\
1999)\end{array}$ & $\begin{array}{c}\text { International sales } \\
\text { (\% of total, } \\
2010)\end{array}$ & $\begin{array}{c}\text { International sales } \\
\text { (Change in \%, } \\
\text { 1999-2010) }\end{array}$ \\
\hline 1 & Walmart & US & 109,539 & 16 & 14 & 26 & +12 \\
\hline 2 & Carrefour & France & 79,248 & 23 & 38 & 59 & +19 \\
\hline 3 & Metro & Germany & 55,112 & 34 & 40 & 61 & +21 \\
\hline 4 & Lidl \& Schwarz & Germany & 40,132 & 26 & 20 & 52 & +32 \\
\hline 5 & Auchan & France & 38,064 & 12 & 19 & 59 & +40 \\
\hline 6 & Aldi & Germany & 33,576 & 18 & 33 & 53 & +30 \\
\hline 7 & Tesco & UK & 31,085 & 14 & 10 & 32 & +22 \\
\hline 8 & IKEA & Sweden & 29,097 & 38 & 92 & 94 & +2 \\
\hline 9 & Ahold & Netherlands & 25,605 & 10 & 76 & 65 & -9 \\
\hline 10 & Rewe & Germany & 24,303 & 13 & 20 & 34 & +14 \\
\hline 11 & Delhaize & Belgium & 21,721 & 6 & 83 & 78 & -5 \\
\hline 12 & Costco & US & 19,581 & 9 & 19 & 25 & +6 \\
\hline 13 & Seven \& I & Japan & 17,803 & 18 & 30 & 31 & +1 \\
\hline 14 & $\mathrm{H} \& \mathrm{M}$ & Sweden & 16,430 & 36 & 84 & 94 & +10 \\
\hline 15 & Amazon & US & 15,497 & 7 & 22 & 45 & +23 \\
\hline
\end{tabular}

Source: derived from IGD's Retail Analysis (igd.com), Deloitte/Stores 2011 Global Powers of Retailing and Annual Reports. Revenue figures for the financial year that corresponds most closely to calendar year 2010. Exchange rates used are for $31^{\text {st }}$ December 2010 and are taken from www.xe.com. Key rates: $\$ 1=£ 0.64=€ 0.75$.

Note: Safeway and Sears discounted from list as sales operations confined to North America only. 
Table 3. Tesco Asia Acquisitions

\begin{tabular}{|c|c|c|c|c|c|c|c|}
\hline Country & Date & Company acquired & $\begin{array}{l}\text { Price } \\
(£ \mathbf{m})\end{array}$ & Mix of consideration & No. stores & $\begin{array}{l}\text { Sales on } \\
\text { acquisition }(£ m)\end{array}$ & Notes \\
\hline \multirow[t]{2}{*}{ China } & Jul-04 & $50 \%$ of Hymall & 148 & & $25 \mathrm{HMs}$ & 330 & PAT of $£ 5.5 \mathrm{~m}$ \\
\hline & Dec-06 & Further $40 \%$ & 181 & 180 cash, 1 asoc costs & & & \\
\hline \multirow[t]{2}{*}{ Malaysia } & Nov-01 & 70:30 JV with Sime Darby & 0 & na & na & na & \\
\hline & Dec-06 & Makro from SHV & 73 & 72 cash, 1 of associated costs & 8 & & c800,000 sq ft space \\
\hline \multirow[t]{7}{*}{ South Korea } & May-99 & $51 \%$ of Samsung Tesco & 85 & & & & \\
\hline & Jun-99 & Further $30 \%$ of Samsung Tesco & 57 & & & & \\
\hline & Feb-02 & Further $8 \%$ of Samsung Tesco & & & & & \\
\hline & Jul-07 & Further $5 \%$ of Samsung Tesco & $40-60$ & & & & \\
\hline & Jul-11 & Further $5 \%$ of Samsung Tesco & & & & & \\
\hline & Mar-05 & Store acquisition from Aram Mart & 49 & 49 cash & 3 CHMs, 9 SMs & $£ 111 \mathrm{~m}$ in $05 / 06$ & c200,000 sq ft space \\
\hline & Apr-08 & Homever stores from E-Land & 958 & & $36 \mathrm{HMs}$ & $\mathrm{c} £ 800 \mathrm{~m}$ & $\begin{array}{l}3 \mathrm{~m} \text { sq } \mathrm{ft} \text { of retail space, } \mathrm{c} 1.3 \mathrm{~m} \text { of } \\
\text { mall space. } 21 \text { freeholds. } 50 \% \text { paid } \\
\text { on acquisition and } 50 \% \text { after sales } \\
\text { uplifts achieved }\end{array}$ \\
\hline \multirow[t]{2}{*}{ Thailand } & May-98 & Lotus & 206 & 117 cash : $89 \mathrm{~m}$ assumed debt & $13 \mathrm{HM}$ & $\mathrm{c} £ 276 \mathrm{~m}$ & \\
\hline & & ASIA TOTAL & 1,757 & & & & \\
\hline \multicolumn{8}{|c|}{ Divested Markets } \\
\hline \multirow[t]{2}{*}{ Japan } & Jul-03 & $\begin{array}{l}\text { C Two Network (convenience } \\
\text { stores) }\end{array}$ & 176 & Cash & 78 & 286 & \multirow{2}{*}{$\begin{array}{l}\text { In August 2011, Tesco announced } \\
\text { its intention to sell its Japanese } \\
\text { business via a phased divestment } \\
\text { process with Aeon. }\end{array}$} \\
\hline & Apr-04 & Frec & 16 & assumed debt & 27 & 146 & \\
\hline Taiwan & Oct-00 & $\begin{array}{l}\text { Acquired } 1 \text { former Makro store at } \\
\text { Tai Mall (Taoyuan) }\end{array}$ & n.d. & Cash & 1 & n.d. & $\begin{array}{l}\text { In } 2005 \text { - Tesco divested the } 6 \\
\text { stores and } 2 \text { sites in asset swap } \\
\text { with Carrefour and receive } 11 \\
\text { stores in Czech Republic and } 4 \\
\text { outlets in Slovakia }\end{array}$ \\
\hline
\end{tabular}

SM - supermarket; HM - hypermarket

Source: Barclays Capital and JP Morgan personal communication with modifications 
Table 4. Tesco Asia: Country Summaries, 2011/12

\begin{tabular}{|c|c|c|c|c|c|c|c|c|c|c|c|}
\hline Country & $\begin{array}{l}\text { Population } \\
\text { (m) }\end{array}$ & $\begin{array}{l}\text { Grocery } \\
\text { Spend } \\
(\$ \text { bn })\end{array}$ & $\begin{array}{c}\text { Year } \\
\text { entered }\end{array}$ & $\begin{array}{l}\text { Sales } \\
2011 / 12 \\
\text { (£m) }\end{array}$ & $\begin{array}{l}\text { Tesco } \\
\text { Market } \\
\text { Share } \\
(\mathbf{2 0 1 2}) \\
\end{array}$ & $\begin{array}{c}\text { Invested Capital } \\
\text { 2010/11 } \\
\text { (£m Cumulative Est.) }\end{array}$ & $\begin{array}{l}\text { Trading EBITDA } \\
\text { Return (Est.) } \\
\text { (2011) }\end{array}$ & $\begin{array}{l}\text { Total Space } \\
(000 \text { sq ft }) \\
(2011 / 12)\end{array}$ & $\begin{array}{c}\text { Store numbers } \\
\text { (Hypermarkets/Other } \\
\text { Stores) } \\
(\mathbf{2 0 1 1 / 1 2 )} \\
\end{array}$ & Clubcard & $\begin{array}{l}\text { Online } \\
\text { Offer }\end{array}$ \\
\hline China & $1,341.41$ & 971 & 2004 & 1,311 & $2.9 \%$ & 801 & $3.9 \%$ & 9,622 & $110 / 14$ & Yes & Yes \\
\hline Japan & 127.47 & 497 & 2003 & 436 & $0.1 \%$ & 463 & $0.6 \%$ & 505 & $0 / 140$ & No & No \\
\hline Malaysia & 28.23 & 31 & 2002 & 891 & $10.2 \%$ & 635 & $7.7 \%$ & 3,778 & $45 / 0$ & Yes & Yes \\
\hline $\begin{array}{l}\text { South } \\
\text { Korea }\end{array}$ & 48.91 & 96 & 1999 & 5,339 & $5.7 \%$ & 3,600 & $13.7 \%$ & 12,551 & $\begin{array}{c}127 / 286(+45 \\
\text { franchised) }\end{array}$ & Yes & Yes \\
\hline Thailand & 67.65 & 56 & 1998 & 3,235 & $13.0 \%$ & 1,375 & $19.6 \%$ & 12,831 & 136/956 & Yes & Yes \\
\hline
\end{tabular}

Source: BOAML (2010); BARCLAYS CAPITAL (2012a); JP MORGAN CAZENOVE (2011); SHORE CAPITAL (2010a; 2010b); TESCO ANALYST PACKS 
Table 5. The Tesco Approach to International Retail Expansion

\begin{tabular}{|c|c|c|}
\hline Build the Network & Build the Brand & Extend the Brand \\
\hline $\begin{array}{l}\text { - Construct scalable store network } \\
\text { - Develop store support operations } \\
\text { such as distribution centres and } \\
\text { sourcing networks }\end{array}$ & $\begin{array}{l}\text { - Evolve a collection of stores into } \\
\text { a retail brand } \\
\text { - Begin to introduce pillar brands } \\
\text { in food and product brands in } \\
\text { general merchandise } \\
\text { - Introduce Clubcard }\end{array}$ & $\begin{array}{l}\text { - Create new platforms for brand } \\
\text { development: internet, financial } \\
\text { services etc. }\end{array}$ \\
\hline
\end{tabular}

Source: adapted from information in Tesco analyst presentations 
Figure 2. Elements of the Tesco Homeplus (South Korea) "Blueprint" of Capabilities Appropriate For Transference

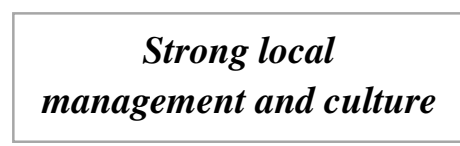

Community focus

Online and retailing services

\section{Strong property portfolio}

Tesco South Korea

Transferable Capabilities

Tesco Operating Model

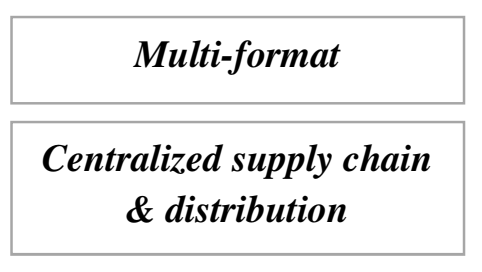

Clubcard \& dunnhumby

Admired brand

Source: adapted from McLLWEE, 2010 


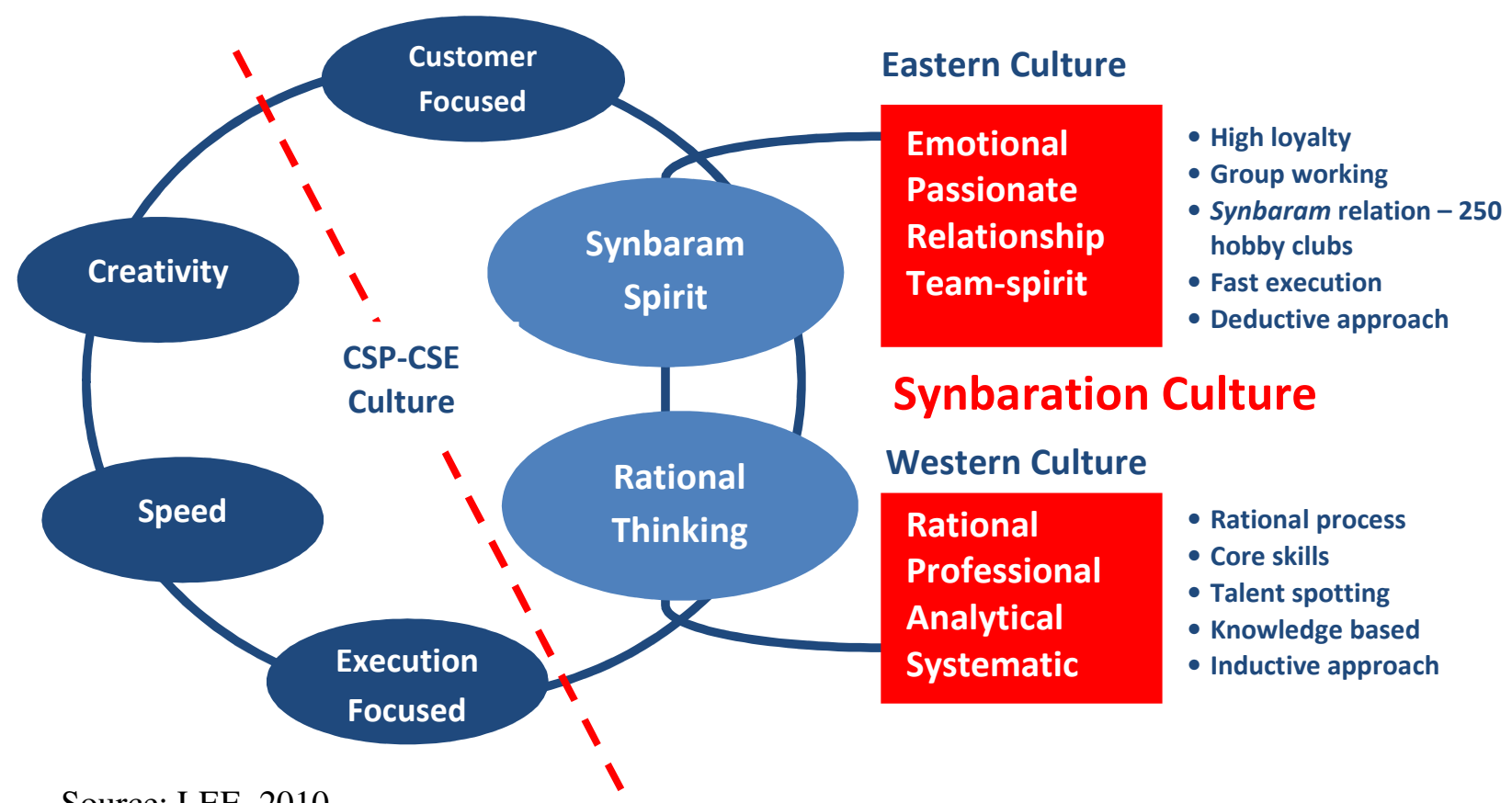

Source: LEE, 2010 


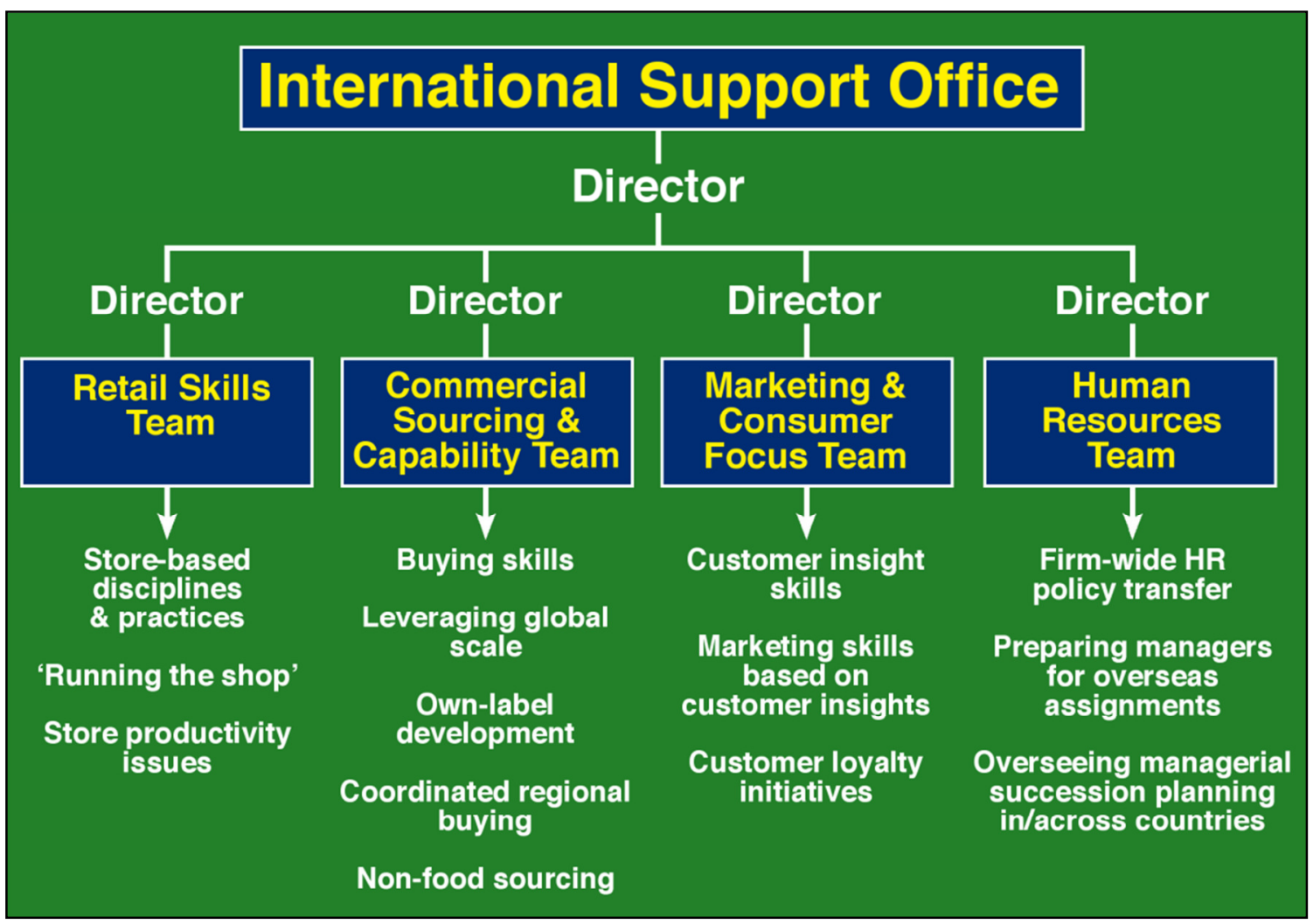

Source: WRIGLEY, 2005 
Table 6. Tesco China Site Research Approach to Analysing Development Opportunities

Step 1: Ranking of target cities

- City Quality Matrix (CQM) ranking developed, based on economic and modern retail indicators, all extensively mapped and then scored

- Key competition measures (e.g. population per mall)

Step 2: Identifying the right districts within cities

- Government meetings to understand future development plans

- Team driving every road, visiting every competitor

Step 3: Identifying best locations within district

- Analysis of catchment spending power (hypermarket + mall)

- Analysis of competition

- Understanding micro-location factors (roads, access, public transport)

Source: adapted from information in Tesco analyst presentations 
Table 7. Regional Focus at Tesco China and Strategic Priorities

\begin{tabular}{|c|c|c|c|c|c|c|c|}
\hline Region & Provinces & $\begin{array}{c}\text { Size } \\
(\mathbf{k m ~ s q})\end{array}$ & Population & $\begin{array}{c}\text { Average } \\
\text { age }\end{array}$ & $\%$ migrant & $\begin{array}{l}\text { \% Employed in } \\
\text { State Owned } \\
\text { Enterprises }\end{array}$ & Strategic Priorities \& Approach \\
\hline North Region & $\begin{array}{l}\text { Hebei; } \\
\text { Beijing; } \\
\text { Tianjin; } \\
\text { Liaoning; } \\
\text { Shandong }\end{array}$ & $522 \mathrm{k}$ & $\begin{array}{l}236 \mathrm{~m} \\
\text { (includes } 34 \\
\text { of the top } \\
100 \text { cities) }\end{array}$ & 41 & 17 & 27 & $\begin{array}{c}\text { Focus on Fresh Food } \\
\text { Further improving the local part of } \\
\text { the offer, particularly on the Deli } \\
\text { Being No. } 1 \text { in every city } \\
\text { Developing the structure and } \\
\text { capability of the team } \\
\text { Opening Blueprint Distribution } \\
\text { Centre }\end{array}$ \\
\hline East Region & $\begin{array}{l}\text { Anhui; } \\
\text { Jiangsu; } \\
\text { Shanghai; } \\
\text { Zhejiang }\end{array}$ & $361 \mathrm{k}$ & $\begin{array}{c}208 \mathrm{~m} \\
\text { (includes } 14 \\
\text { of } 20 \text { most } \\
\text { affluent } \\
\text { cities) }\end{array}$ & 38 & 34 & 15 & $\begin{array}{l}\text { Market leading growth, building on } \\
\text { existing strong positions. } \\
\text { Leveraging the supply chain and } \\
\text { Operating Model. }\end{array}$ \\
\hline South Region & $\begin{array}{l}\text { Guangdong; } \\
\text { Fujian }\end{array}$ & $304 \mathrm{k}$ & $\begin{array}{c}131 \mathrm{~m} \\
\text { (includes } 22 \\
\text { of the top } \\
100 \text { cities) }\end{array}$ & 32 & 62 & 10 & $\begin{array}{l}\text { Increasing new store programme } \\
\text { including LifeSpaceMalls } \\
\text { Building on strong growth } \\
\text { Earning trust in the Tesco brand } \\
\text { Ensuring quality of Fresh Food in } \\
\text { every store } \\
\text { Developing the supply chain } \\
\text { Building the capability of the team }\end{array}$ \\
\hline
\end{tabular}

Source: adapted from information in Tesco analyst presentations 
Table 8. Emerging Central and Regional Structure at Tesco China

In the Centre

Policies, Systems, Processes, Service Centres,

Leveraging Scale, First Among Equals

As much as can be the same:

Financial control and reporting

Commercial: Hardlines, Electronics, Clothing and national FMCGs

Marketing: Insight, Membercard, Trade Planning and Customer Communications

Development/deployment of Operating Model

Ordering, IT, Distribution and Supply Chain

Property Services and Management

Leasehold Mall Management

Human Resources

Source: adapted from information in Tesco analyst presentations

\section{In the Regions}

Tailoring our offer for local customers

As different as it needs to be:

Commercial: local suppliers and regional

divisions of FMCGs

Marketing: local Trade Plan

Operating stores to deliver a consistent Shopping

Trip

Finding and developing the people to enable growth 